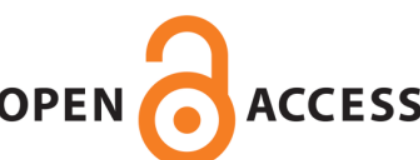

UWS Academic Portal

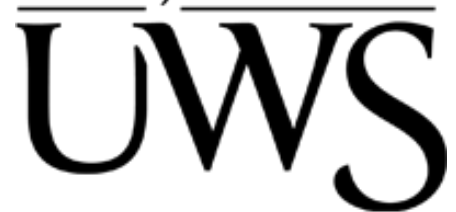

\title{
Brexit and the future of UK fisheries governance: learning lessons from Iceland, Norway and the Faroe Islands
}

Huggins, Christopher; Connolly, John; McAngus, Craig; Van Der Zwet, Arno

Published in:

Contemporary Social Science

DOI:

10.1080/21582041.2018.1516296

Published: 03/04/2019

Document Version

Peer reviewed version

Link to publication on the UWS Academic Portal

Citation for published version (APA):

Huggins, C., Connolly, J., McAngus, C., \& Van Der Zwet, A. (2019). Brexit and the future of UK fisheries governance: learning lessons from Iceland, Norway and the Faroe Islands. Contemporary Social Science, 14(2), 327-340. https://doi.org/10.1080/21582041.2018.1516296

\section{General rights}

Copyright and moral rights for the publications made accessible in the UWS Academic Portal are retained by the authors and/or other copyright owners and it is a condition of accessing publications that users recognise and abide by the legal requirements associated with these rights.

Take down policy

If you believe that this document breaches copyright please contact pure@uws.ac.uk providing details, and we will remove access to the work immediately and investigate your claim. 
"This is an Accepted Manuscript of an article published by Taylor \& Francis Group in CONTEMPORARY SOCIAL SCIENCE on 3 September 2018, available online: http://www.tandfonline.com/doi/full/10.1080/21582041.2018.1516296" 


\title{
Brexit and the future of UK fisheries governance: learning lessons from Iceland, Norway and the Faroe Islands
}

\begin{abstract}
Brexit presents significant challenges and uncertainties for the future governance of policy areas currently managed by the EU. This is especially the case with fisheries policy. The UK government has stated an ambition for post-Brexit fisheries policy to be based on sustainability and the use of scientific evidence. Yet how these aims will be achieved and formalised into post-Brexit governance structures remains to be seen. This article investigates fisheries governance arrangements in three non-EU countries: Iceland, Norway and the Faroe Islands. These cases offer lessons for the UK on governance and institutional arrangements for fisheries post-Brexit. However, none of these cases account for devolution and division of fisheries policy competences across multiple territories. This places signific ant limits on the potential for direct policy transfer from these countries to the UK.
\end{abstract}

Keywords: Brexit; fisheries policy; Ic eland; Norway; Faroe Islands; policy transfer

\section{Introduction}

The United Kingdom's (UK) withdrawal from the European Union (EU) presents significant challenges for the future governance of fisheries (Phillipson \& Symes, 2018). Brexit means that the UK, and its devolved administrations, must develop governance capacities in an area where they have hitherto had limited discretion. They must balance the interests of the catching sector, which overwhelmingly backed Brexit, with a need to ensure the sustainability of fisheries, while also meeting obligations under the UN Convention on the Law of the Sea (UNCLOS) and managing relationships with neighbouring coastal states, including the EU. Furthermore, the UK government will have to carefully manage its relationships with the devolved administrations in Northern Ireland, Scotland and Wales, who have competence over 
fisheries policy but not over key related areas such as international engagement.

While these challenges are considerable, the UK will not be alone as an independent coastal state in the region. Through applying a policy learning approach, this article assesses the fisheries governance regimes in three independent coastal states: Iceland, Norway and the Faroe Islands. While the nature of the fishing industries in each is different (see Table 1), they all have in common Exclusive Economic Zones (EEZs) which border the UK's, and work with the EU to manage their fisheries. These cases offer policy lessons for the UK as it seeks to establish its own fisheries governance framework.

\section{[TABLE 1 HERE]}

The focus of this article is on institutional and governance arrangements, along with their impact on industry and stakeholder engagement, rather than the specific fisheries management policies themselves. Indeed, the impact fisheries policy goes beyond the nature of the fishery itself, and a successful approach requires consideration also be given to questions of governance, institutions, stakeholder participation and community impact (Tirrell, 2017, p. 37). Here, Iceland, Norway and the Faroe Islands offer potential lessons for UK policy-makers post-Brexit. This is especially the case regarding the strength of principles of sustainability, the role of science, engagement with industry and other stakeholders, and the need for transparency in decision-making processes. However, none of these cases account for the devolution and division of fisheries policy competences across multiple territories. This, alongside other contextual factors, places significant limits on the potential for direct policy transfer from these countries to UK fisheries policy post-Brexit.[1]

First, this article summarises the key opportunities and challenges Brexit presents fisheries policy. It then provides an overview of policy learning and policy 
transfer, arguing that learning from examples of fisheries policy governance abroad offers potential lessons for the UK post-Brexit. The fisheries governance systems in Iceland, Norway and the Faroe Islands are then assessed, outlining the main features of each country's institutional structures, decision-making processes and relationships between government and fisheries stakeholders. The article concludes by comparing the lessons from these three countries and considering their applicability to post-Brexit fisheries governance.

\section{B rexit and fisheries policy}

As a member of the EU and participant in the Common Fisheries Policy (CFP) substantive policy-making in UK fisheries policy is done at the EU level. This means the UK government's and devolved administrations' role is essentially one of policy implementation, albeit with limited discretion in some areas. Withdrawal from the EU and the CFP means the UK will become an independent coastal state with decisionmaking and governance responsibility over fisheries policy returning to the UK, alongside full control over its EEZ. Under UNCLOS the UK will have to ensure their approach to fisheries management promotes sustainability and avoids over-exploitation, cooperate with neighbouring coastal states on the management of fish stocks which straddle their EEZs, and grant access to other coastal states where there is a surplus of fish stocks. The immediate challenge for the UK is the possibility of a lack of fisheries governance frameworks in place at the point of EU withdrawal or at the end of any transition period.

On the one hand, Brexit presents the UK with an opportunity to tailor fisheries policy to suit its needs. From a policy perspective this would serve to address some of the perceived failings of the CFP. From a political perspective it would serve to address the unpopularity of the CFP among much of the catching sector. Indeed, survey 
evidence collected before the referendum showed $92 \%$ of fishers intended to vote to leave the EU, with another $92 \%$ believing Brexit would somewhat or greatly improve the fortunes of the fishing industry.

Brexit also presents the UK with significant challenges. The EU has a longestablished and experienced technical secretariat, has built working relationships with industry, the scientific community and other stakeholders, and EU policy-making processes are well established. UK administrations have developed capacities in the day-to-day management and implementation of fisheries policy, and will be able to draw on this. However, post-Brexit they will also need to take on additional roles in policy-making. As with most policy areas associated with Brexit, the UK will essentially be starting from a low-capacity position when it comes to policy development.

The CFP has often been criticised for failing to ensure sustainability of stocks, with Total Allowable Catches (TACs) being set above the levels recommended by scientific advice due to, amongst other things, the nature of political bargaining process between member states' representatives in the Council (Carpenter et al., 2016; Daw \& Gray, 2005; Khalilian et al., 2010). The need to put sustainability at the heart of postBrexit fisheries policy has been backed by scientists, parliamentary committees and industry alike (House of Lords European Union Committee, 2016; Stewart \& O'Leary, 2017), and the government's recently published fisheries white paper commits to the principle of fishing to Maximum Sustainable Yield and basing decisions on scientific evidence (HM Government, 2018). This commitment will need to be reflected in the UK's post-Brexit fisheries regulatory regime, including the setting and distribution of quotas, regulations on gear and access to fishing grounds. 
In developing this regulatory framework, the government will not only have to meet its international obligations to sustainability and science-based policy, but also engage with a range of stakeholders in the fishing industry. This presents another challenge as the sector is diverse and requires to balance the needs of various elements such as the catching sector, the seafood processing sector, and environmental interests. There is significant diversity within individual areas of the fishing sector. For example, the needs of the under-10 metre fleet are fundamentally different from the over-10 metre fleet. Developing working relationships with industry representatives and relevant stakeholders and ensuring transparency in policy-making processes is therefore crucial. Another challenge is managing the relationship between the UK government and the devolved administrations. Indeed, Brexit has the potential for intergovernmental conflict between the competences of devolved administrations and the UK government due to the uncertain and contested character of the UK's territorial constitution (McHarg \& Mitchell, 2017). Much of this arises from the fact that devolved and reserved competencies are not neatly divided, and several policy areas whilst legally devolved are mainly administered at the European level. Fisheries is one example of this, which is further complicated by the fact that the area is devolved but does not operate in isolation from non-devolved policy areas. For example, most of the UK's catch is exported and the UK is a net-importer of fish making international trade an important dimension to fisheries policy (Marine Management Organisation, 2017). As already noted, control over the UK's EEZ comes with an obligation to cooperate with neighbouring coastal states and so international negotiation is crucial.

Currently, the CFP provides an overall framework and point of reference under which the UK operates. The devolved administrations undertake implementation and management of fisheries, but are effectively restricted by the CFP's common 
framework. The UK's withdrawal from the EU and the CFP therefore presents an opportunity for the devolved administrations to play a more active role in shaping fisheries policy in their respective areas. There are advantages to this as the nature of the fishing industry in each of the UK's constituent nations is fundamentally different (see Table 2). For example, Scotland has a dominant position in the UK in terms of fleet capacity and fish landed, reflecting a larger proportion larger vessels, and is largely dependent upon pelagic and demersal fisheries. The English and Welsh fleets, however, are dominated by smaller vessels which are much more focused on shellfish.

\section{[TABLE 2 HERE]}

If the devolved administrations take on a greater role in fisheries then it would allow them to better cater for the needs of their specific fishing industries. However, this may lead to the UK adopting four distinct fisheries policies. While some variation in management and implementation of fisheries policy across the devolved administrations is present under the current arrangements, the CFP's minimum requirements limit the potential for vastly different policy frameworks. Unless these minimum requirements are replaced after the UK withdraws from the EU, for example through a UK-wide common policy framework, there is potential for divergent fisheries policies developing.[2]

\section{The need for policy learning}

Policy learning is essentially about introducing one set of ideas and enabling their implementation within another context to avoid policy failure. Policy-makers will seek to avoid failure if they realise that existing policies are not fit for purpose or reliable due to evidence of adverse political and policy outcomes (Walsh, 2006; Newman \& Head, 2015; McConnell, 2015; Nair \& Howlett, 2017). A key source of policy learning emerges from what Nair and Howlett (2017) call 'policy myopia': the difficulty of 
seeing far enough into the future to discern the general shape of policies in enough detail to anticipate and plan in the present. This is particularly acute for Brexit as the outcomes of the negotiations and their long-term impact remain uncertain. Nevertheless, to avoid the risks of policy failure it is important for the UK to learn lessons from others in order to maximise the opportunities for policy success (Marsh \& McConnell, 2010; McConnell, 2015). Here policy learning is voluntary but arises out of a perceived necessity driven by the challenge of Brexit.

Linked to policy learning is a long-established literature on policy transfer (for example Dolowitz \& Marsh, 1996; 2000; Evans \& Davies, 1999; James \& Lodge, 2003; Stone, 2004; Marsh \& Sharmon, 2009; Evans, 2017). This highlights a range of considerations, including understanding both the 'giving' and 'receiving' context, identifying which actors that should do the transferring, and identifying whether it is possible to transfer policies. In this sense, the task of policy transfer is to understand what could be transferred, rather than treating it as an 'all or nothing' approach (Dolowitz \& Marsh, 2000, p. 13). Rose (2005) offers a more practical approach, which can be summarised as identifying where to look for policy lessons, understanding how those lessons work and how they can be transferred to the new context, deciding whether to apply the lessons and evaluating the outcome of applying the lessons.

In terms of where to look, Rose (2005) advises looking abroad. Within the context of the EU it has been suggested that opportunities for policy learning and transfer are limited as there are no cases to be imitated (Radaelli, 2000). However, this does not apply in the case of fisheries and Brexit. Iceland, the Faroe Islands and Norway are all non-EU coastal states whose EEZs border the UK's and work with the EU to manage their fisheries. Despite differences in the makeup of their respective fishing industries, they all share a similar status to a post-Brexit UK. These three cases 
potentially offer the UK opportunities to draw lessons to determine how post-Brexit fisheries policy may, or may not, be governed.

\section{Fisheries governance in non-EU countries}

\section{Iceland}

Fisheries are important to the Icelandic economy. Despite declining as a share of total exports since the early 2000s, fish and other marine products accounted for $42 \%$ of goods exports and 22\% of total exports in 2015 (Central Bank of Iceland, 2016). Iceland is held up as an example of good fisheries management and its Individual Transferable Quota (ITQ) system is often cited as effectively promoting sustainability and healthy stocks (Kokorsch \& Benediktsson, 2018).

This system was first introduced in 1991. Legally, fish stocks around Iceland are owned by the Icelandic nation and quota rights to catch and land that fish are available to buy, sell and trade in an open marketplace. Within strict rules, which aim to make sure that the allocated quota is extracted, not sold abroad and does not become monopolised by bigger companies, quota holders can utilise the quota market to suit their needs based on previous catches over the past three years. Continuous monitoring and the existence of an online, real-time landings database promotes a culture of openness and transparency (Interview 4; Interview 5).

Icelandic fisheries are governed through a three-pillared structure. First, the Ministry of Fisheries and Agriculture, within the Ministry of Industries and Innovation, is responsible for laws and regulations. Second, the Marine Research Institute (MRI) is responsible for providing the ministry with scientific advice on the health of fish stocks and recommended TAC and quota levels. Despite being a government institute under the auspices of the ministry, its independence is protected by law with government not 
interfering in its operation and adhering its scientific advice very closely. The final pillar is the Directorate of Fisheries which is responsible for the day-to-day administration of fisheries management. The legal and operational independence of the MRI and the Directorate means that, according to officials, fisheries policy has become relatively depoliticised (Interview 2).

Despite becoming strained at times, the overall relationship between the industry and government is positive and there exists a general culture of consensus-building between government and industry. The industry is mostly supportive of the ITQ system and respects the MRI's scientific advice. As well as seeing government as a partner in the management and sustainability of Iceland's fisheries, industry representatives are often closely engaged in external relations, both in more informal bilateral and trilateral settings and in more formal, multilateral settings (Interview 2).

Although Iceland's ITQ system, backed up by its governance and institutional structures, has considerably improved the health of fish stocks in Iceland as well as promoted collegiate relationships between science, industry and government, and received praise from abroad in the process (Yagi et al., 2012), the system has had negative social consequences. The 1991 reforms aimed to limit the power of larger companies when it came to acquiring quota but the system still favours larger enterprises that do not tend to operate in more remote areas. This has led to the overall decline of remote fishing towns and villages. Although the government has taken measures to encourage other industries to counterbalance fishing's decline, the impact on these areas is a recognised negative side-effect of the ITQ system (Agnarsson \& Matthiasson, 2016; Kokorsch \& Benediktsson, 2018).

\section{Norway}

Fishing in Norway represents a relatively small part of the economy, especially when 
compared to the country's oil and gas sector. Nevertheless, it remains politically important, especially to the communities along Norway's coastline. Over the last three decades, Norway has developed a complex fisheries management regime, encompassing strict licensing and ownership rules, a system of TACs and quotas assigned to vessels, and a package of regulatory measures, including a discard ban. Much of this regulatory approach was in response to the collapse of herring stocks in the 1960s and cod stocks in the 1980s (Årland \& Bjørndal, 2002; Gullestad et al., 2015; Mikalsen \& Jentoft, 2003).

Governmental responsibility falls under the Department of Fisheries and Aquaculture, which sits within the Ministry of Trade, Industry and Fisheries. The ministry is supported by several agencies, of which the Institute for Marine Research and the Directorate of Fisheries are the most important. The Institute for Marine Research undertakes scientific research on the welfare of the marine environment and provides scientific advice on fisheries. The Directorate of Fisheries acts as the executive agency for the ministry and has responsibility for much of the day-to-day administration of fisheries policy, both through implementing policy and by undertaking a monitoring and control role. The Directorate also has an advisory function, recommending new fisheries regulations. Norway was the first country to establish a dedicated fisheries ministry in 1946, and the Directorate of Fisheries was established in 1900. This illustrates the importance of fisheries policy to Norway and emphasises Norway's extensive institutional experience in fisheries management.

Three fundamental aims drive Norwegian fisheries policy: sustainability, profitability and the promotion of employment and settlement in coastal communities (Norwegian Government, 2009). These aims have statutory weight and are written into the 2009 Marine Resources Act. This legislation also requires an 'ecosystem approach' 
to the management of marine resources (Gullestad et al., 2009, p. 105). Similar to Iceland, the act states that wild marine resources belong to Norwegian society as a whole.

To achieve these statutory aims, decision-making takes place within a policy cycle known as the 'regulatory chain'. This starts with scientific advice followed by quota negotiations with neighbouring coastal states. It then moves to a period of stakeholder engagement in the form of a 'regulatory meeting' bringing together representatives from the fishing industry, local authorities, environmental organisations and other stakeholders. Based on this input, the Directorate of Fisheries makes proposals for quota allocation and regulations, which are then passed to the ministry for a final decision. This is then followed by implementation and a period of monitoring. This is a cyclical process; experiences of implementing the previous year's regulations feed into the next year's decision-making cycle. This process also ensures a constant interaction between the government, industry, the scientific community and other stakeholders such as environmental NGOs, meaning it is regarded as transparent. Indeed, the working relationship between the various actors is said to be good.

Assessed against the benchmarks of sustainability and profitability, Norway's approach to fisheries management has been successful. The setting of TACs based on scientific advice, coupled with the allocation of quotas and a range of regulatory measures has seen Norwegian fisheries return to sustainable levels (Interview 7). Furthermore, strict licensing and ownership rules, together with the removal of subsidies, have reduced the size of the Norwegian fishing fleet. While preventing overfishing, this also encouraged the remaining fleet to increase productivity and profitability, thus securing the long-term economic viability of Norway's fishing industry (Interview 8; Gullestad et al., 2009, p. 105). 
However, the broader economic context in Norway has been important in ensuring this success. Indeed, at the time the Norwegian fishing fleet was reduced, Norway's economy was relatively strong meaning alternative employment was readily available, mitigating the negative impact on coastal communities (Gullestad et al., 2009, p. 105). Nevertheless, more recent research (for example Tirrell, 2017) has drawn attention to a longer-term negative impact on smaller fishing communities. Quotas have become increasingly more expensive, making it difficult for new entrants and providing incentives for small-scale fishers to sell them to larger fishing enterprises outside of their community, which are consolidating fishing opportunities. This has in turn had wider impacts on smaller communities, which have seen fish processors and other local economic activities close (Tirrell, 2017, pp. 39-40).

Norway's successes in achieving sustainable and economically profitable fisheries have meant there is broad political consensus that the current approach to fisheries management works (Interview 7). Notwithstanding occasional disagreements, the transparent decision-making process and active involvement of a range of stakeholders has meant that the government perceives working relationships with the fishing industry and the scientific community to be positive. Government officials also perceive the fishing industry to be broadly supportive of the government's approach (Interview 7). However, accounts from the fishing industry, particularly the small-scale fleet, highlight that while there is a recognition that Norway's approach to fisheries management has led to improved fish stocks, there is also a dissatisfaction with the longer-term detrimental impact on smaller coastal communities (Tirrell, 2017, p. 40). Furthermore, while the 'regulatory chain' policy-making process actively involves stakeholders, there is a perception that those formally representing the fishing industry do not always adequately reflect the interests of all fishers (Tirrell, 2017, pp. 41-42). 
Consequently, it has been argued that industry co-operation may be more indicative of an overriding culture of compliance in Norway, rather than broad industry support for the government's approach (Gezlius, 2002; Tirrell, 2017).

Another important factor has been the need for bold political leadership in a context where the fortunes of the fishing industry are a salient political issue (Interview [Ervik]). At the time, proposals to more heavily regulate Norwegian fishing activities were controversial and were met with resistance in both Norway's parliament and cabinet (Mikalsen \& Jentoft, 2003, p. 399). Furthermore, the introduction of the discard ban relied heavily on the persistence and leadership of the then fisheries minister (Gullestad et al., 2015, p. 4).

\section{The Faroe Islands}

Fishing is a crucial industry in the Faroes Islands, representing around 95\% of the Islands exports and making a 20\% contribution to total GDP (Ministry of Fisheries and Natural Resources, 2008). The economy can almost be considered a mono-product economy and the prosperity of the Islands stands and falls by the performance of its fishing industry (Búskaparráðið, 2010 cited in Hegland \& Hopkins, 2014).

Pelagic in the Faroe Islands stocks have been managed using a TAC system for which quotas are agreed internationally. However, demersal stocks have been managed using a total allowable effort (TAE) system. This days-at-sea system allocates the number of days that individual fishers have the right to fish. This effort-based system enjoys support from industry and the public (Jákupsstovu et al., 2007), but has been criticised by the scientific community as a free-for-all system with limited restrictions to ensure sustainability (Interview 13). It has also led to criticism that scientific evidence plays a limited role in influencing Faroese fisheries policy (Jákupsstovu et al., 2007; Hegland \& Hopkins, 2014). 
While formally part of the Kingdom of Denmark, the Faroe Islands are completely autonomous in terms of fisheries policy and fisheries management. The Ministry of Fisheries is responsible for fisheries management. Scientific support is provided by the Faroe Marine Research Institute (FAMRI).

Faroese fisheries management centres around determining the number of fishing days which happens on an annual basis (Hegland \& Hopkins, 2014). The ministry receives a scientific report from FAMRI which is shared with a Committee on Fishing Days (CFD) which consists of catching industry representation. The CFD drafts its own report and the minister formulates a bill based on the two reports which is shared for consultation with the Fishery Advisory Council, consisting of a wider group of industry representatives. The minister will present the Bill to the Parliament which takes the final decision.

While this process includes a formal role for scientific advice, there is limited scope for direct interaction between the scientific and industry communities. This has often led to different assessments of the state of fishing stocks and considerable tension (Interview 13, Interview 14). Consequently, the minister's position has often been closer to that of the industry, with scientific advice being at best less influential and at worst ignored (Hegland \& Hopkins, 2014). Another important feature is the lack of environmental interests, which are not only absent from the policy process but also from the wider public debate. This absence means that sustainability and environmental dimensions are less prominently represented in Faroese fisheries policy. While the scientific community sometimes takes on the role of environmental activists (Interview 13), this often leads to scientific evidence has become politicised. This, coupled with a strong industry representation, has often led to conclusions that the Faroese system fails to achieve a level of fishing effort that produces long-term sustainability and is 
internationally perceived as lagging behind (Hegland and Hopkins, 2014). Hegland and Hopkins (2014, p. 8) conclude that the whole system is 'suboptimal as it provides little incentive or support for the integration of diverse views between scientists, managers and industry representatives'.

To address these challenges, the Faroese Parliament passed a bill instigating a major overhaul of its fisheries policy in December 2017. The reforms represent a government pledge to reform fisheries policy, and are built on three pillars: social, economic and ecological sustainability (Government of the Faroe Islands, 2018). The new governance system aims to rebalance the influence of key stakeholder groups in Faroe Islands whilst strengthening public benefit from fisheries. Environmental sustainability is to be achieved by enhancing the influence of scientific evidence. One of the major changes is that the effort-based system is replaced by a system of TACs. This will allow for a greater use of scientific evidence in the policy-making process as quotas will be determined by a set formula, 'protecting' the system from politicisation of decisions. Nevertheless, it is not yet clear how the institutional structures will facilitate increased interaction between industry and science (Interview 10).

These reforms take place within a wider context. First, they are part of a larger package which aims to ensure that the wealth of Faroese fisheries would be more equally distributed. There have been concerns about the lack of public benefit from fisheries; resource fees, antitrust rules and an auction system for fishing licences aim to move away from privately and concentrated ownership of licenses and maximise public benefits. Second, although in an international context the Faroese system had some longstanding unique features, the recent reforms demonstrate a move towards international convergence and adopts a much more similar approach to their immediate neighbours, Norway, Iceland and the EU. 


\section{Discussion and conclusion}

The UK government has stated an intention for post-Brexit fisheries policy to be led by the principle of sustainability and for decisions to be based on scientific evidence (HM Government, 2018). Yet the UK will also have to balance a diversity of interests within the fishing industry to ensure support for its approach. The three cases discussed in this article highlight some important lessons, particularly regarding governance and institutional design, commitment to sustainability and relationships with industry and other stakeholders.

For example, in Iceland and Norway, a three-pillared institutional design consisting of a government ministry, an independent scientific institute and a day-to-day management directorate, coupled with a strong legal framework ensuring the independence of the scientific advice and importance of sustainability, have led to a situation where stocks in are comparatively healthy. Coupled with this are constructive and broadly consensual relations with the fishing industry, and transparency and openness in decision-making processes, fostering trust between policy-makers and stakeholders. The Faroe Islands offer a contrasting experience. The absence of environmental NGOs has meant scientific advice has often become politicised, and has pitched the scientific community against the fishing industry, which in turn has called into question the overall sustainability of Faroese fisheries policy. Indeed, it is telling that reforms passed in December 2017 now move Faroese fisheries much more into line with the approach taken by Iceland and Norway.

While much attention has been on the UK leaving the CFP and developing its own approach to post-Brexit fisheries governance, the UK is able to draw on its existing experience when drawing these lessons. In England, for example, the separation of political and policy responsibility from the day-to-day implementation of fisheries policy is already reflected in the respective roles of the Department for Environment, 
Food and Rural Affairs and the Marine Management Organisation. Although still vague, commitments in the recently published fisheries white paper (HM Government 2018), such as basing fisheries decisions on scientific evidence and encouraging industry involvement in policy-making, also highlights how UK government thinking may already be drawing from the experiences in other coastal states.

Nevertheless, the examples of Iceland, Norway and the Faroe Islands also draw attention to the potential limits of learning lessons. The process of constructing effective fisheries governance took these countries several years. There are also differences in context. All three cases have fishing industries that are more important to their economies than in the UK's case, where fishing only accounts for around $0.05 \%$ of GDP. The nature of the UK's fishery and the geography of its seas, which means there are multiple shared stocks in relatively confined spaces, is also fundamentally different from the three cases discussed.

Each case also highlights potential pitfalls in direct policy transfer, as policy ideas in each have led to unintended consequences. For example, the introduction of the ITQ system in Iceland has seen fishing opportunities become consolidated among larger enterprises and led to the decline of more remote coastal communities (Agnarsson \& Matthiasson, 2016). In Norway, efforts to reduce the size of the fishing fleet to make it more sustainable and economically profitable have also seen quotas become more expensive, making it difficult for new entrants into the industry. While Norway's 'regulatory chain' ensures stakeholder participation in fisheries policy-making, there have also been criticisms that some representatives do not adequately represent the diverse interests of the while fishing industry (Tirrell, 2017).

Finally, none of the three examples tackle the question of devolution. The UK's membership of the CFP has served a constitutional purpose in maintaining the balance 
between regional divergences on the one hand and commonality across the UK on the other. The removal of this overarching has created a vacuum within which differing interests at the regional and national level are engaged in a struggle between the articulation of difference and enforcement of commonality respectively. The case studies outlined in this article are useful in proposing institutional and policy frameworks that can result in successful fisheries management regimes outside the CFP, but they do not talk to the multilevel and intergovernmental nature of governance in the UK. Any learning from institutional and policy frameworks elsewhere will have to navigate these multilevel and intergovernmental contours. The question of at what level particular competencies ought to lie and to whom different levels of government are accountable will need to be settled, although this may take some time as initial arrangements may prove to be inadequate. In other words, the UK will have to learn from its own experiences after Brexit. Nevertheless, the broad structure of fisheries governance in non-EU coastal states and the broad principles on which it is based offer a potentially useful guide from which the UK can learn.

Overall, then, this article demonstrates both the potential and limitations of policy transfer as a way for the UK to shape post-Brexit governance. It remains to be seen whether Brexit will be totemic-shifting or will produce a more absorbable process of gradual policy and bureaucratic adjustment following a transition period. Nevertheless, the need for policy learning from other contexts across policy sectors, particularly those that are affected by the EU, has become ever more acute. Yet as the policy transfer and learning literature and the three cases presented in this article stress, policy-makers need to be aware of the challenges of doing so, including having a 'goodness of fit' between the lessons drawn and the bureaucratic capacities and expertise to enable their implementation. For the UK, the added complexities include 
the extent to which there is political agreement across levels within its multi-level policy system regarding whether the right lessons are being adopted and whether the policy lessons align with industry interests and public opinion. This is not only relevant for the governance of the UK fisheries policy, but also resonates across all policy areas affected by Brexit.

\section{Endnotes}

1. This article draws on a review of existing literature and relevant policy documents. It also draws on interviews with 20 fisheries policy-makers and stakeholders in Iceland, the Faroe Islands and Norway, conducted between October 2017 and January 2018. A full list of interviews is available in the online appendix.

2. There also remain uncertainties about future access to the UK's EEZ to non-UK vessels and the access to neighbouring EEZs by UK vessels, and questions about the future of trade for fish products. See Phillipson and Symes (2018) for a full discussion of the challenges Brexit presents UK fisheries policy.

\section{References}

Agnarsson, S., Matthiasson, T., \& Giry, F. (2016). Consolidation and distribution of quota holdings in the Icelandic fisheries. Marine Policy, 72, 263-270.

Årland, K., \& Bjørndal, T. (2002). Fisheries management in Norway-an overview. Marine Policy, 26, 307-313.

Carpenter, G., Kleinjans, R., Villasante, S., \& O'Leary, B. C. (2016). Landing the blame: The influence of EU Member States on quota setting. Marine Policy, 64, $9-15$.

Central Bank of Iceland. (2016). Economy of Iceland. Retrieved from: https://www.cb.is/library/Skraarsafn---EN/Economy-ofIceland/2016/Economy_of_Iceland_2016.pdf

CIA. (2017). World Factbook, Europe, Faroe Islands. Retrieved from: https://www.cia.gov/library/publications/the-world-factbook/geos/fo.html Daw, T., \& Gray, T. (2005). Fisheries science and sustainability in international policy: A study of failure in the European Union's Common Fisheries Policy. Marine Policy, 29(3), 189-197. 
Dolowitz, D., \& Marsh, D. (1996). Who learns what from whom: a review of the policy transfer literature. Political Studies, 44(2), 343-357.

Dolowitz, D., \& Marsh, D. (2000). Learning from abroad: The role of policy transfer in contemporary policy- making. Governance, 13(1), 5-23.

Evans, M. (ed.). (2017). Policy Transfer in Global Perspective. Abingdon: Routledge

Evans, M., \& Davies, J. (1999). Understanding policy transfer: A Multi- level, multidisciplinary perspective. Public Administration, 77(2), 361-385.

Eythórsson, E. (1996). Theory and practice of ITQs in Iceland. Privatization of common fishing rights. Marine Policy, 20(3), 269-281.

FAS. (2017). Faroe Islands national and international ship register. Retrieved from: http:/fas.sansir.net/Default.aspx

Fiskeridirecktoratet. (2017). Norwegian fishing vessels, fishermen and licenses 2016.

Retrieved from:

https://www.fiskeridir.no/content/download/18557/266899/version/7/file/f iskefa rtoy-etc-2016.pdf

Gezelius, S. S. (2002). Do Norms Count? State Regulation and Compliance in a Norwegian Fishing Community. Acta Sociologica,45(2), 305-314.

Government of the Faroes Islands. (2018). The Faroese Parliament passes fisheries reform. Retrieved from: http//www.government.fo/news/news/the-faroeseparliament-passes-fisheries-reform/

Gullestad, P., Blom, G., Bakke, G., \& Bogstad, B. (2015). The "Discard Ban Package": Experiences in efforts to improve the exploitation patterns in Norwegian fisheries. Marine Policy, 54, 1-9.

Gullestad, P., Abotnes, A. M., Bakke, G., Skern-Mauritzen, M., Nedreaas, K., \& Søvik, G. (2017). Towards ecosystem-based fisheries management in Norway Practical tools for keeping track of relevant issues and prioritising management efforts. Marine Policy, 77, 104-110.

Hagstova Føroya. (2017). Faroe Islands in figures. Retrieved from: http://www.hagstova.fo/sites/default/files/Faroe_Islands_in_figures_2017.pdf

Hegland, T. J., \& Hopkins, C. C. E. (2014). Towards a new fisheries effort management system for the Faroe Islands? - Controversies around the meaning of fishing sustainability. Maritime Studies, 13(12), 1-24.

HM Government. (2018). Fisheries white paper: sustainable fisheries for future generations. Retrieved from: 
https://www.gov.uk/government/consultations/fisheries-white-paper-

sustainable-fisheries-for-future-generations

House of Lords European Union Committee. (2016). Brexit: fisheries (HL Paper 78).

Retrieved from:

https://publications.parliament.uk/pa/ld201617/ldselect/ldeucom/78/78.pdf

Jákupsstovu, S. H., Cruz, R., Maguire, J. J., \& Reinert, J. (2007). Effort regulation of the demersal fisheries at the Faroe Islands: a 10-year appraisal. ICES Journal of Marine Science, 64, 730-737.

James, O., \& Lodge, M. (2003). The limitations of 'policy transfer' and 'lesson drawing' for public policy research. Political Studies Review, 1(2), 179-193.

Khalilian, S., Froese, R., Proelss, A., \& Requate, T. (2010). Designed for failure: A critique of the Common Fisheries Policy of the European Union. Marine Policy, 34(6), 1178-1182.

Kokorsch, M., \& Benediktsson, K. (2018). Prosper or perish? The development of Icelandic fishing villages after the privatisation of fishing rights. Maritime Studies, Pre-published online.

Marine Management Organisation. (2017). UK Sea Fisheries Statistics 2016. Retrieved from: https://www.gov.uk/government/collections/uk-sea-fisheries-annualstatistics

Marsh, D., \& McConnell, A. (2010). Towards a framework for establishing policy success. Public Administration, 88(2), 564-583.

Marsh, D., \& Sharman, J. C., (2009). Policy diffusion and policy transfer. Policy Studies, 30(3), 269-288.

McConnell, A. (2015). What is policy failure? A primer to help navigate the maze. Public Policy and Administration, 30(3-4), 221-242.

Mcharg, A., \& Mitchell, J. (2017). Brexit and Scotland. British Journal of Politics and International Relations, 19(3), 512-526.

Mikalsen, K. H., \& Jentoft, S. (2003). Limits to participation? On the history, structure and reform of Norwegian fisheries management. Marine Policy, 27, 397-407.

Ministry of Fisheries and Natural Resources. (2008). Faroe Islands Fisheries \& Aquaculture - Responsible Management for a Sustainable Future. Retrieved from: http://www.government.fo/news/news/faroe-islands-fisheries-aquacultureresponsible-management-for-a-sustainable-future/ 
Nair, S., \& Howlett, M. (2017). Policy myopia as a source of policy failure: Adaptation and policy learning under deep uncertainty. Policy \& Politics, 45(1), 103-118.

Newman, J., \& Head, B. W. (2015). Categories of failure in climate change mitigation policy in Australia. Public Policy and Administration, 30(3-4), 342-358.

Norwegian Government. (2009). Act relating to the management of wild living marine resources (Marine Resources Act). Retrieved from: http://app.uio.no/ub/ujur/oversatte-lover/data/lov-20080606-037-eng.pdf

Phillipson, J., \& Symes, S. (2018). 'A sea of troubles': Brexit and the fisheries question. Marine Policy, 90, 168-173.

Radaelli, C. M. (2000). Policy transfer in the European Union: institutional isomorphism as a source of legitimacy. Governance, 13(1), 25-43.

Rose, R. (2005). Learning from Comparative Public Policy: A Practical Guide. Abingdon: Routledge.

Statistics Iceland. (2018). Total catch in 2017 was nearly 1,177 thousand tonnes. Retrieved from: http://www.statice.is/publications/news-archive/fis heries/fishcatches-in-december-2017/

Statistik Sentralbyrå. (2018a). Statistics Norway: External trade in goods. Retrieved from: http://www.ssb.no/en/utenriksokonomi/statistikker/muh/aar

Statistik Sentralbyrå. (2018b). Statistics Norway: Fisheries. Retrieved from: https://www.ssb.no/en/jord-skog-jakt-og-fis keri/statistikker/fiskeri

Stewart, B. D., \& O'Leary, B. C. (2017). Post-Brexit Policy in the UK: A New Dawn? Fisheries, Seafood and the Marine Environment. Retrieved from: http://ukandeu.ac.uk/wp-content/uploads/2017/07/Bre xit-Fis heries-seafood-andmarine-environment.pdf

Stone, D. (2004). Transfer agents and global networks in the 'transnationalization' of policy. Journal of European Public Policy, 11(3), 545-566.

Tirrell, A. (2017). Socioculutral institutions in Norwegian fisheries management. Marine Policy, 77, 37-43.

Walsh, J. I. (2006). Policy failure and policy change: British security policy after the Cold War. Comparative Political Studies, 39(4), 490-518.

Yagi, N., Clark, M. L., Anderson, L. G., Arnason, R., \& Metzner, R. (2012). Applicability of Individual Transferable Quotas (ITQs) in Japanese fisheries: A comparison of rights-based fisheries management in Iceland, Japan, and United States. Marine Policy, 36, 241-245. 
[6,235 words] 
Table 1. Iceland, Faroe Islands, Norway and UK fishing industries compared

\begin{tabular}{|l|l|l|l|l|}
\hline & Iceland & $\begin{array}{l}\text { Faroe } \\
\text { Islands }\end{array}$ & Norway & UK \\
\hline $\begin{array}{l}\text { Total catch (thousand tonnes, } \\
\text { 2016) }\end{array}$ & $1,069.9$ & 568 & $2,065.5$ & 701.1 \\
\hline Number of vessels (2016) & 1,647 & 365 & 5,946 & 6,191 \\
\hline Number of fishers (2016) & $\begin{array}{l}\text { Approx. } \\
6,000\end{array}$ & 1,460 & 11,249 & 11,757 \\
\hline $\begin{array}{l}\text { Value of fish and seafood as a } \\
\text { proportion of exports }\end{array}$ & $\begin{array}{l}22 \% \\
(2015)\end{array}$ & $\begin{array}{l}97 \% \\
(2016)\end{array}$ & $\begin{array}{l}6.7 \% \\
(2017)\end{array}$ & $\begin{array}{c}0.27 \% \\
(2016)\end{array}$ \\
\hline
\end{tabular}

Source: CIA (2017); FAS (2017); Fiskeridirecktoratet (2017); Hagstova Føroya (2017);

HM Revenue and Customs (2018); Marine Management Organisation (2017); Statistics Iceland (2018); Statistik sentralbyrå (2018a, 2018b).

Table 2. Comparing the fishing industry across the UK's nations

\begin{tabular}{|l|l|l|l|l|}
\hline & England & $\begin{array}{l}\text { Northern } \\
\text { Ireland }\end{array}$ & Scotland & Wales \\
\hline Number of vessels 10m and under & 2,569 & 202 & 1,456 & 419 \\
\hline Number of vessels over 10m & 529 & 149 & 575 & 32 \\
\hline Total fleet capacity (tonnes) & 58,813 & 13,916 & 105,395 & 5,186 \\
\hline Number of fishers & 5,306 & 875 & 4,823 & 753 \\
\hline $\begin{array}{l}\text { Total landings by nationality of } \\
\text { vessel (thousand tonnes) }\end{array}$ & 201.6 & 29.4 & 453.3 & 9.9 \\
\hline $\begin{array}{l}\text { Total value of landings by nationality } \\
\text { of vessel (£ million) }\end{array}$ & 304.7 & 41.6 & 556.9 & 21.7 \\
\hline
\end{tabular}

Source: Marine Management Organisation (2017) 